\title{
LOCAL AND REGIONAL PUBLIC MANAGEMENT REFORMS IN SWITZERLAND
}

\author{
KUNO SCHEDLER
}

Public management reforms at the local (community) and regional (canton) level in Switzerland almost all embrace elements of the new public management. In addition, in Switzerland, the merging of small communities as well as new developments such as electronic government are becoming apparent. The new public management model has been adapted for Swiss needs according to the perception of decision makers on problems that require solution in a Swiss context. NPM has developed, therefore, into rather different models in practice, aimed at the solution of these diverse problems. Foreign examples, such as the Dutch Tilburg Model and the German Neues Steuerungsmodell, played a major role at the start of this process, but have continuously lost their influence as actual models to be emulated. The most outstanding peculiarities of the Swiss reforms are an early and subsequent outcome focus together with the strong influence of direct democracy.

\section{INTRODUCTION}

Switzerland is perceived in European circles as a small independent but diverse country. Indeed, it has approximately only six million inhabitants (of which 19 per cent are foreign nationals) who live in four different linguistic regions. In spite of its small size, it is divided into 26 cantons (which are more or less sovereign states) and close to 3000 communities (local authorities). When talking about Switzerland in this paper, we are looking at a three-tier system that includes a national level, a cantonal level and a local level (communities and cities). More than half of the communities have less than 1000 inhabitants. It may not come as a surprise, therefore, that the average Swiss community has approximately 2500 inhabitants.

Swiss local authorities have a wide range of duties to fulfil. Their responsibility embraces complex areas such as education (mostly up to the secondary school level), social welfare, infrastructure, water and electricity supply, and so on. In this respect, Swiss communities do not resemble their Englishspeaking counterparts in, for instance, the modern Commonwealth or the USA, but are more akin to the Dutch and German communities.

Reforming the public sector in Switzerland is unavoidably linked to highly political processes and debates. Although the political commitment of the Swiss has decreased over the last few years, the opportunity to take part in direct democratic decision-making encourages a permanent general awareness of pressure groups, partisan statements and issues arising on the political agenda.

Kuno Schedler is in the Institute of Public Services and Tourism at the University of St Gallen. 
This paper will examine local and regional public management reforms that have occurred since the start of the debates about 'New Public Management' in Switzerland and the time period covered is that of the late 1980s and the 1990s. As there can be no future without the past, and as no reform model can be understood in isolation from the contextual peculiarities of a particular political and administrative system, previous reforms will be described and the context and circumstances of the current reforms will then be analysed. Currently, Swiss communities are in the process of a piecemeal implementation of new elements of managerial control, often without a greater vision of a 'New Public Management'. Nevertheless, the latter term is so widely (and sometimes somewhat/oddly) used that it is at risk of losing its true significance and credibility.

Additionally, this paper will aim to provide a general understanding of the Swiss reforms at the local level and their peculiarities in comparison with two other papers in this volume from The Netherlands and Germany. Finally, we will seek to locate similarities and differences between the three examples under scrutiny from the Swiss public management perspective.

\section{CONTEXT AND CIRCUMSTANCES}

\section{Organizational context}

A single, typical organizational structure for Swiss local authorities does not exist. As a general rule, we can expect the political and administrative system at the Swiss local level to consist of four main elements:

1. A full assembly (Gemeindeversammlung) or - most often as a result of the larger size of the local community - a representative body comparable to a parliament, but named differently, determined by the respective cantonal law.

2. A 'governing' city council embracing an average of six executive politicians.

3. A handful of political committees, either elected by the full assembly or by the representative body.

4. The community administration, the members of which work on an unlimited contract basis. Most often, only a very few actual civil servants are elected by the council. In these cases, they work on a four-year fixed appointment basis.

In some cantons, different types of communities overlap a geographical region. So-called 'political communities' are generally responsible for public services, while so-called 'citizen communities' look after their inherited citizen members. Not unusually, they are great owners of land and forests and use their economic wealth for the benefit of their members. The difference between the two types can be explained by a peculiar Swiss regulation: by birth, every Swiss is a citizen of a certain community - independent of the fact of where he or she is living and exercising his or her citizen's rights at the time. In addition, there is a third type of community (which fairly often 
TABLE 1 Economic statistics for the Swiss communities, 1997-98

\begin{tabular}{llc}
\hline Year & Category & Amount \\
\hline 1998 & Communities' fiscal quota according to & 5.2 \\
& OECD statistics as percentage of GDP & \\
1997 & Communities' revenues (Swiss francs) & 37.9 billion \\
& Percentage growth rate since 1990 & 28.7 \\
1997 & Communities' expenditure (Swiss francs) & 38.4 billion \\
& Percentage growth rate since 1990 & 27.1 \\
1998 & Percentage communities' borrowings & 10.1 \\
& Percentage comparison with 1990 & 9.1 \\
1998 & Percentage communities' state quota & 10.3 \\
& Percentage growth rate since 1990 & 8.4 \\
\hline
\end{tabular}

Source: Federal Financial Administration and Federal Statistical Office.

exists separately) namely, the so-called 'school communities'. These are financed either by the political community or by raising their own school tax. Both forms can be found in contemporary Switzerland.

\section{Economic context}

Traditionally, the communities have represented the government level with the least financial problems. Communal expenditure may have risen by 130 per cent from 1990 to 1998 (see table 1), but all in all, communities are not suffering from strong financial pressure. Deficits remain modest in size. This is not, however, the case in the major cities, which suffer from the added burden of being geographical centres. During the above-mentioned period, prominent 'expenditure drivers' were higher vocational training (a factor of 10.7), hospitals and nursing homes (a factor of 12.4), health insurance (a factor of 13.6) and social welfare (a factor of 9.7), while relief was provided by the abolition of mandatory contributions towards roads, railways and national defence.

For a long time, that is until the time of the financial insolvency of one single community (Leukerbad) in the late 1990s, communities were regarded indisputably as excellent borrowers; they were always granted the best terms and conditions on the money and capital markets, comparable with the issuing of government bonds. Since communities raise their own fiscal revenues, they are also relatively autonomous - at least as long as they do not depend on equalization payments from the canton. Even in expert circles, the opinion prevailed that the cantons are responsible for the settlement of their communities' debts if the unlikely case of insolvency should occur.

The Leukerbad case in the late 1990s dramatically changed this situation: the canton responsible, the Canton of Valais, refused to provide a guarantee, and the creditworthiness of all Swiss communities then became a matter to be reviewed. By now, every major Swiss bank has a system to assess 
communities' and cantons' creditworthiness, and this has an immediate impact on the communities' funding conditions - and is further pressure for them to organize themselves efficiently. In spite of this, however, it may be said that the pressure for Swiss communities to reform did not arise from a financial crisis as seems to be the case in Germany and, partially, the Netherlands.

\section{Political context}

Local authorities in Switzerland vary widely in the way they are governed. To present them as having a single political ideology would be simplistic, but there are certain common trends that can be observed:

- In general, larger cities have been governed by left-of-centre coalitions for at least the last thirty years, although changes in majorities have also occurred. In the 1960s, these cities were wealthy and therefore invested in extensive infrastructure development programmes, which included public transport systems, theatres and even universities. By later years, infrastructure problems had been solved and were replaced by welfare programmes such as community housing, support of one-parent families, and so on.

- This move from economic development policies to 'social engineering' policies created new hazards as social housing left no space for 'good' tax payers to live in the big cities. The result was a vicious circle with a rise in welfare spending that had to be backed up by tax rises, which in turn led to tax payers - and increasingly even companies - leaving the cities and thereby decreasing tax revenues. To understand this context, one has to be aware that Swiss local authorities do have a fairly high share of local taxes and set the level for these taxes autonomously.

- Throughout the next decade, we can expect to see city governments which will have to get out of this vicious circle by changes in their ideological approach. Community housing will have to be cut in favour of expensive living areas for richer people and tax burdens will have to be decreased. It remains unclear, however, if this turn-around can be successful at all.

- In smaller communities, the down-to-earth pragmatism of citizens and the Bauernschläue (a type of shrewdness characteristic of farmers) that had been developed over centuries of hardship in the face of an often unfriendly environment, has prevented the implementation of left-wing policies. As a consequence, right-of-centre parties such as the Liberal Democrats, the Christian Democrats, and the People's Party have enjoyed safe majorities there throughout nearly all the German-speaking cantons since World War II.

There are, however, much greater tensions in Switzerland than the political left-wing vs. right-wing difference: this country is still culturally divided by its wide range of languages and various cultures, but also by Catholic and Protestant traditions. Although they are politely hidden, the diverse religious 
roots of the various regions can still be traced by an insider. Although many young people have no knowledge of these hidden ties, certain cultural elements still live on across succeeding generations.

\section{Direct democracy as a peculiarity}

On a scale which quantifies direct democratic influence by the citizens of European countries, all three tiers of government in Switzerland would achieve a number-one ranking. Swiss democratic rights include the possibility of either instigating a Referendum against a new law that has passed parliament, or handing in an Initiative, which proposes a new law or article. At local level, it is not uncommon to hold full assemblies, where decisions on the yearly budget, the tax level, as well as single-case spending on, say, a new roundabout or a new snowplough, are taken.

Although only 30-50 per cent of the electorate take part in ballots on a regular basis, the right to vote is jealously guarded, and over the last few years, every attempt to limit democratic rights in favour of the greater efficiency of the system in total has been successfully challenged. Thus we are led to the most important precondition for reforms in Switzerland: comprehensive democratic compatibility. Not only is it indisputable that the visionary concept to be implemented should be compatible with the existing democracy, but also the process of experimentation and implementation needs to follow democratic principles. Thus, consensus about the reforms has to be built up before formal steps to parliament and/or the electorate are taken.

\section{PREVIOUS REFORMS}

It has already been mentioned that over the last hundred years, only a limited number of reforms have taken place. The Swiss democratic system is characterized by so-called 'concordance' coalitions (Konkordanzdemokratie). That is to say that Swiss cantonal governments, as well as parliaments, are composed of all the major parties and, as decisions are made by situational coalition majorities, there is no institutionalized opposition. This leads to a peculiar situation in which parliaments take on the role of a 'mellow' opposition against the government and in which compromises are made even before a particular decision in its draft form passes into the political decisionmaking process. In this context, 'big bang' reforms are unlikely to happen and it is no surprise that the Swiss participant in the Carl Bertelsmann Prize for the best-run City in the world, Neuchâtel, was not ranked top (see Naschold and Daley 1999, p. 26ff.).

At the local level, large cities face a similar situation to the cantons due to their comparable organizational structure, whereas politics in smaller communities without parliaments is generally less partisan, being driven by the pragmatic intelligence of their local councillors. Thus, in order to become successful, any kind of reform has always been expected to be a gradual process. The new reform type, however, is characterized by a faster pace. 


\section{Fiscal equalization and division of functions}

When in the 1960s some of Switzerland's European neighbours decided to reform their communities geographically by enforcing mergers of smaller communities into larger ones, Switzerland resisted this trend. There was, however, an ongoing debate about the vertical division of functions between the cantonal and the communal level, combined with the rise of so-called fiscal equalization systems. These were implemented to reduce the fiscal disparity between communities within a certain canton, but also throughout Switzerland.

Reforming the division of functions and implementing fiscal equalization was dominated by a regional economic logic. At that time, managerial aspects were not given any priority. Functions were to be divided on the basis of expected spill-over effects as well as efficient allocation of resources. Above all, however, there was political resistance to dramatic changes of the system stemming from deep-rooted cultural phenomena such as mistrust and local rivalries between the neighbouring communities.

Additionally, it appears that since the 1970s, communities have had to cope with an increasing variety of tasks that have been passed down to them by the Federal Government and the cantons, especially in the course of growing financial pressure which was the result of economic recession and internal structural problems. As a consequence, the debate on a new division of functions has been rekindled in the 1990s.

\section{Implementing an accrual accounting system}

In 1970, after a 30-year period of experimentation with various cash and accrual accounting models in cantons and communities, the Conference of Cantonal Finance Ministers set up a committee to devise a standard system. Seven years later, the Conference approved a 'Public Sector Accounting Manual', which required the implementation of a new accrual accounting model at cantonal and communal levels. Its purpose was to secure a greater degree of financial transparency. In 1981, the manual was extended in terms of its regulation for communities. Although the model was widely published and recommended, and software was promptly developed for the market, its implementation status after twenty years is still sketchy. According to Stadler (1994, p. 5), only 70 per cent of communities and 85 per cent of cantons had introduced the manual's recommended accounting model by 1994. These figures have changed only slightly since.

Nevertheless, Switzerland was among the first countries to develop an accrual accounting system for its public sector and the model is still considered to be useful. In the late 1990s and in the context of a larger debate about 'New Public Management', the Conference of Cantonal Finance Ministers decided to co-finance a research project that aimed at developing a harmonized cost accounting system which fits the existing accounting model. 


\section{Challenging local autonomy}

The autonomy of local authorities has been a major topic for debate since the end of World War II. As was mentioned above, the range of functions to be fulfilled by the local authorities has gradually grown, which has confronted smaller communities with the realization that a small community system is no longer capable of fulfilling the functions demanded by the law. Many chose, therefore, to join so-called 'task agencies' (Zweckverbände), public/ public partnerships managed by specialists of the respective function, which took over responsibility for clearly defined tasks for their member communities. The latter are represented by delegates at yearly assemblies and economically underwrite the agencies. Many would argue that these agencies suffer from a lack of democratic accountability. Indeed, not only are task agencies immunized against direct democratic control, but the member communities also give up their autonomy in the short and middle term to these agencies. In the long term, they can withdraw from the contracts.

However, only a few alternatives appear to exist in political practice. The small size of the communities has led to a lack of competence and capacity which in turn leads to insufficient fulfilment of tasks. Mergers between communities are - mostly for unspoken cultural reasons - not realizable, and task agencies are problematic too. Only one solution is likely to succeed in the situation described and it is the one that was indeed implemented in the 1990s: a withdrawal of functions by the cantons. Consequently, the communities lost autonomy over certain tasks but won others - which freed them up to concentrate on and gain autonomy over the remaining tasks.

In the late 1990s, a new trend could be discerned: the corporatization of task agencies into new entities under private law. In a large-scale survey, Schedler and Knechtenhofer (2000) discovered that 65 per cent of all the Swiss communities with more than 3000 inhabitants hold shares in companies incorporated under private law - most frequently in the field of the provision of public services. This is not without its snags since clear rules for corporate governance of such private shares held by communities are largely missing. However, communities, joint-stock companies are able to operate closer to the market than can task agencies. In addition, private law contains enough rules and regulations for the control and monitoring of such operations. Not least, there is also the hope that thanks to such privatization, shared structures can be created which are of sufficient size to prevent any further withdrawals of tasks by the cantons.

\section{PUBLIC MANAGEMENT REFORMS}

\section{Wirkungsorientierte Verwaltungsfiuhrung - the Swiss way towards modernization}

Since about 1993, the early movers among Switzerland's local authorities have followed a general trend to implement public management reforms of the type 'New Public Management' (NPM). As with Germany, the outstanding 
TABLE 2 Elements of the New Public Management in Switzerland

\begin{tabular}{llll}
\hline & $\begin{array}{l}\text { Problems: input } \\
\text { control intransparency }\end{array}$ & $\begin{array}{l}\text { Problems: inflexibility } \\
\text { monopoly behaviour }\end{array}$ & $\begin{array}{l}\text { Problems: bureaucracy } \\
\text { Political Over-Control }\end{array}$ \\
\hline Targets & $\begin{array}{l}\text { Control through } \\
\text { outputs and outcomes }\end{array}$ & $\begin{array}{l}\text { Creation of pressure to } \\
\text { adjust }\end{array}$ & $\begin{array}{l}\text { Enablement of better } \\
\text { management }\end{array}$ \\
Implementation & $\begin{array}{l}\text { Instruments for results- } \\
\text { oriented control }\end{array}$ & $\begin{array}{l}\text { Market-type } \\
\text { mechanisms }\end{array}$ & $\begin{array}{l}\text { Creation of semi- } \\
\text { autonomous entities }\end{array}$ \\
\hline
\end{tabular}

example for Swiss cities was the Dutch City of Tilburg (see also Reichard in this journal) whose concern-division model created attention due to its clear separation of political and managerial roles, or in other words: the Swiss reformers were fascinated by the impression made by the Tilburg model that it was possible to formulate non-arbitrary performance contracts between a political body (City Council) and the Administration. At the same time, that is, in the early 1990s, the New Zealand approach to public management was studied by Swiss researchers and as early as 1994, the two models were compared and combined for Swiss purposes. Ernst Buschor, former St Gallen Professor of Public Management and at present Minister of Education in the Canton of Zurich, named these reforms 'Wirkungsorientierte Verwaltungsführung' (result-oriented public management, Buschor 1993).

'New Public Management' seems to have become a standard international model for reform. However, international comparative analyses of public sector reforms throughout the developed world show that there is no such thing as the 'New Public Management', although most countries use the same terminology and - superficially - the same concept of reform. Most reform agendas use catch-phrases that have been known for many years (see Hood 1991, p.3 ff as an early source):

- increase in efficiency and effectiveness ('doing more with less');

- decentralization of decision-making processes ('let the managers manage');

- steering by outputs rather than inputs and clarification of targets through performance agreements ('steering rather than rowing');

- flattening hierarchical structures by the creation of partially autonomous entities and agencies with lump-sum budgets;

- introduction of market-type mechanisms (marketization);

- introduction of private sector-style management instruments such as cost accounting, marketing, or human resource management.

In Switzerland, New Public Management is seen as a reaction to three major deficiency areas: (1) input control and opacity of outputs and impacts, (2) inflexibility caused by a lack of market pressure, and (3) bureaucracy and excessive political control of operative decisions (see table 2). While NPM projects in a narrower sense (those which are called NPM) focus mainly on 
points (1) and (3), there is a wider trend towards corporatization, marketization and partial privatization that drives point (2): the introduction of markettype or pure market mechanisms. The reformers of the Swiss Post, for example, as well as those of the Swiss Railways, officially declare that they have taken many conceptual ideas from the New Public Management debate. It has become common Switzerland-wide for state-owned entities with greater autonomy to be controlled through performance contracts or performance agreements.

\section{Interpreting practical reforms}

A deeper analysis of the practical applications of reforms reveals a stronger diversity than could be extrapolated from a cursory reading of documents purportedly adhering to the same theoretical concepts. At least, the terminology of such shining examples as New Zealand and/or the United Kingdom has been adopted by champions of reforms at regional and local levels in Switzerland, but whether this signifies a comparable implementation of the model itself is another question. If it is true that the real difference between reform practices cannot be examined by reading the rhetoric of national, regional or local reform projects, we will have to find a way to get below the surface. One way of doing this is the analysis of priorities that has been given to the different elements of the new public management model (see figure 1).

It is argued here that a pure comparison of the reform terminology in publications between Dutch, German, and Swiss communities will not lead to a truly representative result. In order to understand the underlying 'real' situation in these communities, one has to interpret the priorities given to

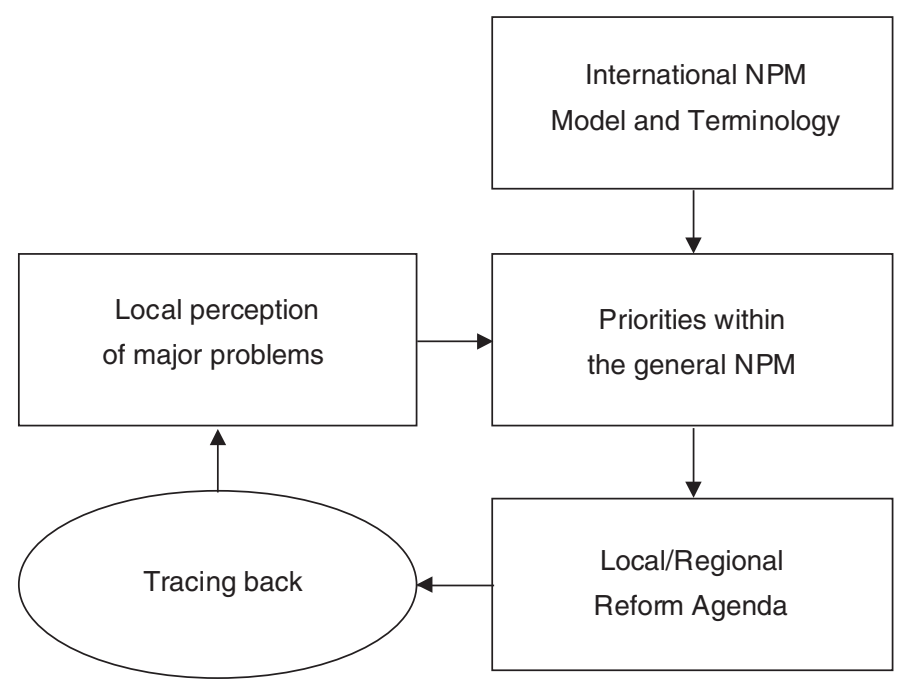

FIGURE 1 Tracing major problems perceived by decision-makers 
certain elements of the NPM model and terminology by the political or administrative reformers. Additionally, the way NPM terms are used and filled with a context will have to be analysed, as the different reformers generally create their own particular reality around the expressions applied. The 'true' local reform agenda - if there is anything like a shared agenda at all - has to be derived from the specific contextual use of the model and terminology of a reform.

Ladner et al. (2000, p. 130) found in their research that one third of German-speaking Swiss communities claim to be undertaking reforms of the 'New Public Management' type. Although a purely quantitative view will most certainly not be able to provide any insight into the real reform situation, it is nevertheless able to give indications in a cross-comparative perspective. The elements that are reformed most often in Swiss communities are shown in table $3(n=2333)$.

As table 3 shows, reforms in human resource management are most often undertaken in Swiss municipalities, while NPM-specific performance management instruments such as surveys, performance contracts, lump-sum budgets, or product definitions have only a limited degree of implementation. It can be said, therefore, that many claims to have implemented the new public management have a bias towards certain (single) elements and do not

TABLE 3 Priorities in Swiss local government reforms in order of magnitude

\begin{tabular}{|c|c|c|}
\hline Reform measure & $\begin{array}{l}\text { Share } \\
(\%)\end{array}$ & Category $^{1}$ \\
\hline 1. Performance-related pay & 17 & Human resource management \\
\hline 2. Abolition of the public servant status (tenure) & 17 & Human resource management \\
\hline 3. Personnel and organizational development & 14 & Human resource management \\
\hline 4. Mission statements for local politics & 13.5 & Strategic management \\
\hline $\begin{array}{l}\text { 5. Delegation of competencies from politicians to } \\
\text { public servants }\end{array}$ & 13.5 & Managerialism \\
\hline $\begin{array}{l}\text { 6. Increased involvement of external experts and } \\
\text { companies }\end{array}$ & 13.5 & Marketization \\
\hline $\begin{array}{l}\text { 7. Devolution of output processes to private } \\
\text { suppliers }\end{array}$ & 13 & Marketization \\
\hline $\begin{array}{l}\text { 8. Better separation of strategic and operational } \\
\text { missions }\end{array}$ & 12.8 & Managerialism \\
\hline $\begin{array}{l}\text { 9. Support of competition between external } \\
\text { suppliers }\end{array}$ & 12 & Marketization \\
\hline 10. Management control systems & 11 & Managerialism \\
\hline 11. Citizens and customers surveys & 10 & $\begin{array}{l}\text { NPM-specific performance } \\
\text { Management instruments }\end{array}$ \\
\hline 12. Performance contracts, performance agreements & 9.5 & $\begin{array}{l}\text { NPM-specific performance } \\
\text { Management instruments }\end{array}$ \\
\hline 13. Lump-sum budgets & 7 & $\begin{array}{l}\text { NPM-specific performance } \\
\text { Management instruments }\end{array}$ \\
\hline 14. Product definitions & 4.5 & $\begin{array}{l}\text { NPM-specific performance } \\
\text { Management instruments }\end{array}$ \\
\hline
\end{tabular}

${ }^{1}$ Measures have been categorized by the author. 
guarantee that the whole repertoire of NPM is used in practical reforms. The fact that elements of marketization and managerialism are of more or less similar importance to local authorities when reforming is also interesting.

\section{Human resource management reforms}

For years, most Swiss local authorities have only changed slightly in terms of human resource management. Due to their fairly small size, bureaucracy has not conquered communities, but even today many cities still suffer from it. In the 1990s, individualistic incentive systems were considered modern and many politicians and managers hoped to overcome bureaucratic attitudes within larger administrations by implementing them (Schedler 1993).

That said, the fact that current Swiss local reforms set highest priority on implementing new human resource management instruments will not come as a surprise to us and gives an indication of an underlying perceived problem. It seems obvious that local councillors and administrative managers locate specific needs to change the way personnel, which are considered to be the primary resource of good government, are treated. Quite surprisingly, measures which erode the egalitarian system, such as performance-related pay and the abolition of tenure, are implemented in parallel with teambuilding measures such as personnel development. Clearly, there is a strong belief in the benefit that derives from implementing private sector-type management methods, which could well be caused by the intensive, but also narrowing, discussion about New Public Management.

\section{Strategic management}

In the field of strategic management, few initiatives in fact are undertaken in Swiss communities. Although there seemed to be a wave of initiatives to formulate mission statements for local authorities in Switzerland in the 1990s, there is little impact for NPM reforms as these projects are mostly isolated from an overall view of public management problems. Some communities were experimenting with strategic management control tools, such as the Balanced Scorecard, in the late 1990s. However, there is no real tendency that can be observed throughout a minimal amount of communities.

It seems that the system of direct democracy in combination with coalition governments is a restraining factor in the implementation of strategic management. The Canton of Berne started a project to design strategic cockpit systems for its communities relatively recently, in 2001. The outcome of this project is still unknown, but the fact that a canton supports efforts of this type is a sign that strategic management is being accorded growing importance.

\section{Managerialism}

The implementation of management instruments that resemble those in the private sector, combined with an increase in managerial freedom and responsibility ('room to manoeuvre'), is generally described as managerialism. 
In the Ladner et al. (2000) survey, managerialism contains the following elements:

- delegation of competences from politicians to public servants;

- better separation of strategic and operational missions;

- management control systems.

The Swiss model of NPM (Wirkungsorientierte Verwaltungsführung) tries to increase administrative managers' managerial responsibility by introducing a twin tool set: performance contracts and lump-sum budgets. As a champion of New Public Management, one would have expected the three managerial elements to be linked with these 'NPM-specific' performance management instruments. However, it seems that many communities try to find a way towards managerialism without using typical NPM instruments.

\section{Marketization}

Major changes in market-oriented behaviour in Swiss communities occurred due to the adjustment of Swiss laws following WTO and/or EU procurement regulation. Former providers of regional and local authorities did not uniformly welcome the fact that a formal procurement process would now have to be gone through regularly. Critics are therefore fairly active, and the future will show if the present regulation will be upheld.

The general trend towards liberalization and deregulation has left its traces in Switzerland: it is mostly in telecommunications, public transport, electricity and, within limits, the water supply, as well waste-disposal, that privatization and corporatization have taken place, even at the regional and local level.

It would be incorrect to trace these changes back to the New Public Management debate. On the contrary: local authorities that undertake reforms of the NPM type most often exclude the marketization element from their reform programme.

\section{NPM-specific performance management instruments}

The relativity of proclamations in Switzerland can be shown perfectly with the fact that - although a large number of communities say that they are using NPM-specific performance management instruments such as surveys, performance contracts, lump-sum budgets and product definitions rank last in table 3, above. Steiner (2000, p. 175) draws the conclusion that 'the current activities primarily have a culture dimension.... and certain aspects of a goal and performance dimension'.

\section{Explaining Swiss reforms}

Indeed, empirical evidence for strong generalizations at the local level is too weak. Switzerland has not an evaluation tradition such as France or the Nordic countries, therefore evaluating reforms has not been considered a standard procedure for public authorities. Systematic evaluations have 
taken place (Econcept 2000; Econcept 2000a; Farago 2000; Rieder and Bächtiger 2000; Rieder and Furrer 2000; Rieder and Farago 2000) but only on the cantonal level, which may differ from the local level in some aspects. Nevertheless, it is possible and necessary to interpret modernization developments in Swiss local government, using as a support the few contributions to systematic empirical evaluations related with the issue and the author's practical experience from engagement in several projects. At the moment, immediate impact of evaluation cannot be proved analytically.

\section{Perception in the communities}

The survey conducted by Ladner et al. (2000), combined with the experience we were able to gain in practical work with reforming communities, accentuate two important perception aspects, as outlined below.

Firstly, New Public Management is only perceived in a very diffuse light. NPM is confused with fears that all the profitable public-sector operations would be privatized while losses would be socialized, that NPM would lead to a rigorous reduction in public-sector jobs, that NPM would accord the already excessively powerful public administration even more influence, that NPM would make communities superfluous, and that economic concerns would prevail above any other concern which has so far been of significance for government activities, such as education, social equalization, etc. At the same time, NPM arouses hopes, namely that statistics should at last make it possible for government institutions to be checked for efficiency, that managers of communal operations should be able to act on the market with complete autonomy, and that - last but not least - ambitious costcutting goals should be achieved. Finally, political practice wraps any change of any kind in the reform slogan of 'New Public Management' - even the purchase of a new fire engine.

Secondly, it has turned out that the perception of problems in Swiss communities focuses on a few clearly definable points rather than criticizing the communities' entire political and administrative system. As a consequence, comprehensive NPM reforms tend to be rare, even though with a clearly rising trend. Single-issue reforms with clear focal points, such as the abovementioned personnel reforms, reinforcement of strategic leadership, and so on, are to be found more frequently.

\section{Characteristics}

Swiss reforms typically vary depending on different factors that explain some of the variations. These are outlined below.

Language and regional culture: Ladner (2001) found that the French-speaking part of Switzerland (Romandie) differs in its reforms from the Germanspeaking part. Due to a different view of the state, the hierarchical distance in the relationship between the state (and its administration) and the citizens is greater in the Romandie with its culture étatisme than it is in the German 
part, where a stronger egalitarian culture dominates. Reforms are consequently focusing on different aspects: efficiency is gaining ground in the French-speaking part, effectiveness and customer service in the Germanspeaking part. In the Ticino, the Italian-speaking part of Switzerland, hardly any NPM reforms have been observed yet.

State level: Switzerland's reform motors are not the local authorities but the cantons. 24 out of 26 cantons have been experimenting with, or are already implementing New Public Management elements. In 2000, four large cantons made a definitive decision to change the bureaucratic system to an NPM-type administration, while cities such as Zurich, Winterthur, St Gallen and Lucerne, along with their parliaments, still seem to uphold a more conservative attitude towards these reforms. Berne, however, is a brilliant and exceptional example of a reforming city in Switzerland. All in all, one could say that the most spectacular modernization other than privatization and corporatization happens at the cantonal, that is state, level. On the other hand, Steiner (2000, p. 185) found that the impetus for NPM reforms at the local level comes mainly from local governments themselves.

No variation due to political left/right paradigms: It is striking that at the onset of the New Public Management wave in Switzerland, no political or ideological positioning occurred. Instead, proponents and opponents of NPM can be made out along the lines of existing power structures. If the reforming executive is dominated by right-wing parties, the left-wing parties will oppose the reforms, and vice versa. In Berne, this has resulted in a somewhat paradoxical situation whereby in the city, the right-wing parties are fighting against the reforms which their fellow party members are implementing at cantonal level - and vice versa.

\section{Driving forces}

Major actors: The reforms are most often led by small but strong groups of administrative staff, in general working in 'internal service offices' such as the human resource office, the treasury, or IT and organization offices. Quite often, we find one outstanding supporter within the government at the cantonal level, while the other four to six cantonal ministers appear to be more restrained. First election results demonstrate that these outstanding reformers are successful due to their active attitude towards modernization and therefore acquire good election results. Some exceptions, however, have already occurred when politicians had to make use of their new managerial strength by, say, making incapable managers redundant. Here, it has become clear that political rationality is still predominant as soon as such an action gains public attention.

Managerial reforms in the first phase: In the early 1990s, the development of a Swiss common reform model (the 'Wirkungsorientierte Verwaltungsführung') 
was strongly influenced by cooperation between early reform projects (Cantons of Lucerne and Berne, City of Berne) and researchers (mainly at the University of St Gallen). It is considered a great success factor today that the conceptualizing groups were able to keep the reforms out of political conflicts as well as juridical debates. This is not to say that there were no politicians or lawyers who worked on the creation of these concepts - however, discussions were never public and therefore did not have to follow strong political or legal rationalities.

Wide interdisciplinary discussion in the second phase: From the late 1990s, that is after the completion of a more or less harmonized reform model, several further disciplines entered the theoretical and empirical debate, above all the legal profession (see Mastronardi and Schedler 1998). We have to mention here that in Switzerland, a deep and profound discussion of New Public Management reforms is still taking place, and since 1998, systematic evaluations of the reforms have become standard procedure for political decision-makers.

Fiscal pressure: Although it is unmistakeable that individual communities (for instance, the City of Berne, which is now conducting reforms) are struggling with serious financial problems, the eagerness to carry out reforms cannot be explained as being a consequence of financial pressure alone. A correlation cannot be made either statistically (see Ladner 2001), or by means of quantitative analyses.

Periodic waves: Although no evaluation has been made of this factor for Switzerland yet, the subject of reform seems to have had a wave-like career since WWII. With a time rhythm of approximately ten years, the Swiss public sector has experienced reform debates that had their peaks in the middle of each of the last four decades: in the 1960s, fiscal equalization was implemented in Switzerland; in the 1970s, it was the financial management reform that introduced a new accounting system; the 1980s saw the overhead cost analysis struggle for more efficiency, but also the destruction of trust in reforms; and the 1990s were dominated by the NPM discussion. It is likely that Electronic Government will take the place of NPM in the first decade of the new millennium. After all, there seems to be an ongoing fight against bureaucracy and inefficiency that uses contemporary reform models for its purpose when reforms are swept into the political agenda again.

Size and environment: A present-day review of the current reforms in Swiss communities reveals that NPM is being implemented particularly in medium-sized cities which possess the foundation in cantonal law (and the experience) necessary to become active in this field. The Cantons of Berne, Zurich and Basel particularly did important preparatory work for their communities, and they also have communities of the 'right' size of 10000-50000 
inhabitants. For smaller communities, the spotlight tends to be more on an intensification of cooperation with others, whereas bigger communities are fighting against resistance from the (major) political bodies (Steiner 2001).

\section{Restraining factors and resistance}

Various elements can be regarded as restraining factors of faster or more successful reforms. Many promoters of administrative reforms, particularly in political bodies, lack an awareness of the significance of administrative culture. Now as before, public administration is regarded as the machinetype of organization that can be modified by decree. In conjunction with a lack of leadership awareness and a lack of leadership training for public managers, this has a partially grave impact on the process of change. Reforms are killed not so much by their concepts as by their deficient implementation.

Administrative reform is an investment whose return can only be achieved after a long time lag. Many (but by no means all) projects lack the financial and personnel resources that would be necessary for success. Such projects are literally being 'dried up'.

Between the politicians' expectations and the actual observable results, there is a time gap which sometimes exceeds politicians' tolerance thresholds. In addition, it has turned out to be difficult to install reliable performance measurements systems. The promised results orientation, in particular, can be implemented only after a long time lag. The combination of these two factors is making politicians increasingly more sceptical of NPM.

Citizens in general do not realize which reforms are on the way and whether or not they may have positive or negative effects on them. Media comment on some of the reforms tends to be occasional (for an overview of articles see http:/ /coc.idt.unisg.ch); public interest, however, is limited. This changes, however, immediately as soon as certain professional groups are hit by reforms, as was the case in the health care sector or the schools in some cantons.

Left-wing parties in particular put up increasing resistance against NPM reforms as they fear the loss of trade union influence and a growing pressure on civil service salaries. Additionally, left-wing partisans argue that NPM is one more stone in a greater mosaic aiming to destabilize the welfare state and its companion, service public (that is, the public sector).

Lastly, many public sector treasurers fear a loss of financial control over their communities due to the implementation of lump-sum budgets and are sceptic about the reforms. The treasurer of the city of St Gallen, Harringer (2000, pp. 505ff.), has become a widely known critic by challenging - among others - the following elements in the context of the NPM model:

- Pricing of products is elementary for competitive testing and other market-type mechanisms. This, however, creates a need for internal costing, which consumes time and resources. 
- The possibility for agencies to carry over parts of their unspent budget to the next year creates a problematic incentive system in that agencies will try to build up reserves and maximize their budgets - which is the opposite of what was intended.

- NPM focuses on the yearly budget as a control instrument. In practice, the budget is not nearly as important as NPM makes people believe; a middle-term focus on financial plans is much more important.

Although some of the critical points do have some justification, critics in Switzerland seem to concentrate on an early NPM model which was too managerial. Meanwhile, inspired by the interdisciplinary debate, the model has been further developed and enriched with political elements. Today, at least in theory, Switzerland can build on a balanced model for modernization.

\section{Perspectives for the future}

Reichard (see article in this volume) defines different 'generations' of model on offer for modernization in Germany. A similar development can be observed in Switzerland. It is obvious that theoretical concepts - and this includes, in particular, our own - are increasingly committed to pragmatic feasibility rather than to theoretical completeness. Additionally, it is clear that the entry of the legal profession (and, in a limited manner, of political science) into the NPM debate at the end of the 1990s resulted in more comprehensive and more holistic concepts of NPM. The status of parliaments, in particular, has been enhanced so that on occasion, the legislators are better informed than the political executives. To this extent, we may speak of a second generation of results-oriented public management (or, in analogy with Reichard, a WoV 2.0), which is highly likely to have greater chances of implementation.

What direction will a possible WoV 3.0 take? In my view, the following future developments can be discerned:

- WoV 3.0 will have to integrate the partial privatizations of community operations that are now taking place into its control concept. This will be worked on under the headings of 'Public Governance' or 'Corporate Governance for Public Institutions'.

- WoV 3.0 will also have to find solutions for those cases in which political instances refuse to admit genuine one-line budgets for public administration. This will be about ensuring the public managers' autonomy in an appropriate manner by means of other measures.

- Wov 3.0 will, in addition, have to develop solutions to intensify the integration of the political executive into the new control system. It is imperative that this deficit is eliminated if medium-term counterreactions from this angle are to be prevented.

\section{SIMILARITIES AND DIFFERENCES}

The Swiss like to be different - and they are most probably not alone in this. Nevertheless, some reform elements seem to be similar in the three countries 
TABLE 4 Similarities and differences

\begin{tabular}{lll}
\hline & Similarities & Differences \\
\hline $\begin{array}{l}\text { Context of the } \\
\text { reform }\end{array}$ & Financial pressure & $\begin{array}{l}\text { NL as an early mover, GER and } \\
\text { CH as late movers } \\
\text { Direct democracy in CH }\end{array}$ \\
$\begin{array}{ll}\text { Contents of the } \\
\text { reform }\end{array}$ & $\begin{array}{l}\text { International NPM concept as a basis } \\
\text { for the national model } \\
\text { Contract model and product } \\
\text { definitions as central elements for the } \\
\text { reform }\end{array}$ & $\begin{array}{l}\text { Indivial use of the international } \\
\text { CH: outcome focus, NL and GER: } \\
\text { output focus }\end{array}$ \\
& $\begin{array}{l}\text { Strong influence of consultants } \\
\text { Implementation } \\
\text { strategies }\end{array}$ & $\begin{array}{l}\text { Starting point in GER and NL: } \\
\text { local government; in CH: state } \\
\text { level } \\
\text { Active involvement of researchers } \\
\text { in the concept phase in CH }\end{array}$ \\
& $\begin{array}{l}\text { Active involvement of politicians } \\
\text { in CH and NL }\end{array}$ \\
& $\begin{array}{l}\text { concern-division model } \\
\text { Supporting reform trend: } \\
\text { eGovernment }\end{array}$ & $\begin{array}{l}\text { NL: start with financial } \\
\text { management; GER and CH: } \\
\text { financial management reforms as } \\
\text { a reaction to general } \\
\text { administrative reforms }\end{array}$ \\
& $\begin{array}{l}\text { involved and do not explicitly } \\
\text { support the reforms }\end{array}$ &
\end{tabular}

under observation, while some others are not. In sum, the different political systems seem to be responsible for most of the dissimilarities between the three countries. On the one hand, Switzerland supports a pragmatic and non-bureaucratic administrative culture (in contrast to Germany, but maybe similar to the Netherlands); on the other hand, Switzerland is conducting a slow and late reform movement (in contrast to the Netherlands, but similar to Germany).

Then again, there are quite a few similarities (see table 4). Both Germany and Switzerland adopted the Tilburg model for their communal reforms in the early 1990s. Owing to the language they have in common, researchers in both countries focused on the same or similar issues: product budgets and reshaping of the budgetary process, decentralization, introduction of costefficiency mechanisms including cost accounting and controlling, and so on (Wollmann 2000, pp. 925 ff.). The original discussion in The Netherlands itself was virtually disregarded - any knowledge about The Netherlands was second hand, and developments in other cities, such as Delft, passed the German-speaking area by.

Hendriks and Tops (1999) have described the cross-cutting main areas of local government modernization in Germany and The Netherlands: 'In the Netherlands, the focus on efficiency and other managerial values in the 1980s shifted to participative policy making in the 1990s. In Germany the focus on the Renewal of Politics from Below in the 1980s, shifted to self management and contract management in the 1990s. In short: what was emphasized in the Netherlands in the 1980s, was accentuated in Germany in the 1990s; and what was emphasized in the Netherlands in the 1990s, had 
been the prime focus in Germany in the 1980s' (Hendriks and Tops 1999, p. 149). Even so, the participatory evolution in Germany has not come to an end during the phase of NPM dominance: Wollmann (2000, p. 929) pointed out that in Germany 'the hitherto existing power arrangement and institutional balance in the local population, the elected council and the local administration... have been conspicuously changed', introducing direct democracy procedures and (re-)discovering the concept of the 'citizen commune' in the 1990s.

However, in Switzerland direct democracy and participation has been the central element of political culture and practise for a long time. In these terms, the Swiss reforms would not be comparable to The Netherlands or Germany. The focus on management reforms is equivalent to Germany, as they significantly expanded not until the 1990s - a decade later than in The Netherlands.

As developments in Switzerland have progressed, foreign examples, such as the Tilburg model and the German Neues Steuerungsmodell, have continuously lost their weight as actual models to be emulated. The focus of concept development is increasingly on solutions to this country's own, in other words, Switzerland-specific problems, and there is hardly any actual exchange between the Netherlands, Germany and Switzerland. The strong influence that could be discerned at the beginning - primarily in one direction, namely from the outside into Switzerland - has largely abated, and the 'pilgrimages' to the relevant shrines have become less numerous. This results in a tendency for different products to be developed in greater isolation once more, without profiting from mutual exchange.

All in all, though, it may be said that despite all the diversities, the differences between the three countries are smaller than the differences between themselves as a group and the Anglo-American models. Neither has the City Manager Model from the USA and New Zealand been able to gain ground here, nor are conditions in the three countries comparable with the new centralism that can be perceived in, say, the UK. Scandinavian citizens may be given a mental pat on the back for their initiatives, but they are not really emulated. Finally, it may not least be on account of the language barriers that not much notice is taken of developments in France, Spain and Portugal. Against this backdrop, the similarities outweigh the differences, and it is perfectly justified for the three countries to communicate their reforms to each other and regard each other as examples - as they have done for some years now. This is likely to continue to be the right way for the future.

\section{ACKNOWLEDGEMENT}

This paper has greatly profited from the assistance and remarks of several friends and colleagues, among them Walter Kickert (Rotterdam), Andreas Ladner (Berne), Christoph Reichard (Potsdam), Orsolya Csobor (St Gallen), and John-Philipp Siegel (St Gallen). 


\section{KUNO SCHEDLER}

\section{REFERENCES}

Buschor, E. 1993. Wirkungsorientierte Verwaltungsführung. Zurich: ZHK.

Econcept. 2000. Evaluation von WOV Kanton Aargau. Zürich: Econcept.

Econcept. 2000a. Evaluation des WOV-Versuches im Kanton Luzern. Zurich: Econcept.

Farago, P. 2000. Evaluation des Pilotprojekts 'Neue Verwaltungsführung' (NEF) im Kanton Bern, 2. Etappe. Zurich: Landert Farago Davatz \& Partner.

Harringer, R. 2000. ‘Das Globalbudget als Zentral - und Schwachstelle im Modell der “Wirkungsorientierten Verwaltung', Schweizerisches Zentralblatt, No. 10/2000, 505-25.

Hendriks, F. and P. Tops. 1999. 'Between democracy and efficiency: trends in local government reform in the Netherlands and Germany', Public Administration, 77, 133-53.

Hood, C. 1991. 'A Public Management for all Seasons?', Public Administration, 69, Spring 1991, 3-19.

Knechtenhofer, B. and K. Schedler. 2000. Die Finanzverwalter/innen in einem veränderten Umfeld Herausforderungen und Perspektiven, internal working paper.

Ladner, A. 2001. 'Gemeindereformen in der Schweiz: Strategien, Gemeinsamkeiten und Auslöser', Swiss Political Science Review, 7, 1-24.

Ladner, A. et al. 2000. Gemeindereformen zwischen Handlungsfähigkeit und Legitimation. Berne: Institute for Organization and Human Resource Management at the University of Berne.

Mastronardi, P. and K. Schedler. 1998. New Public Management in Staat und Recht. Ein Diskurs. Berne: Paul Haupt.

Naschold, F. and G. Daley. 1999. 'Learning from the pioneers: modernizing local government. Part one, International Public Management Journal, 2, 25-51.

Rieder, S. and C. Bächtiger. 2000. Beurteilung der Einführung von Administration 2000 im Kanton Wallis. Lucerne: Interface.

Rieder, S. and P. Farago. 2000. Vergleichende Evaluation der NPM-Projekte in den Kantonen Aargau, Luzern, Solothurn, Wallis und Zürich. Lucerne and Zurich: Interface and Farago Davatz \& Partner.

Rieder, S. and C. Furrer. 2000. Evaluation des Pilotprojektes Leistungsauftrag mit Globalbudget im Kanton Solothurn. Lucerne: Interface.

Schedler, K. 1993. Anreizsysteme in der Öffentlichen Verwaltang. Berne: Paul Haupt.

Steiner, R. 2000. 'New public management in Swiss municipalities', International Public Management Journal, 3 , 169-90.

Steiner, R. 2001. Intermunicipal cooperation and municipal mergers in Switzerland. Local authorities in search of an optimum organizational size for the fulfilment of tasks. Berne: Institute for Organization and Human Resource Management at the University of Berne.

Wollmann, H. 2000. 'Local government modernization in Germany: between incrementalism and reform waves', Public Administration, 78, 915-36.

Date received 22 February 2001. Date accepted 5 July 2002. 